\section{Mødre støtter mødre ved postpartumdepresjon}

Kvinner uten sosialt nettverk har økt risiko for postpartumdepresjon. Nå har forskere fra Canada og USA undersøkt om støtte fra kvinner som selv har hatt slik depresjon, kan forebygge lidelsen (BMJ 2009; 338: a3064).

701 kvinner fra sju ulike helseregioner i Canada ble rett etter fødsel antatt å ha høy risiko for å utvikle depresjon. Disse ble randomisert til å motta telefonstøtte innen 48-72 timer, fra kvinner som nettopp var blitt friske av den samme lidelsen.

Etter 12 uker var det $14 \%$ i intervensjonsgruppen og $25 \%$ i kontrollgruppen som viste tegn til postpartumdepresjon $(p<0,001)$. Ut ifra etiske hensyn ble alle med depresjon ved 12 uker henvist til behandling. I intervensjonsgruppen var over $80 \%$ tilfreds med telefonstøtten og ville anbefale dette til andre.

\section{Nanoteknologi i infeksjonsmedisin?}

Effektiv monitorering av antigenspesifikke T-celler kan benyttes både i diagnostisering og oppfølging av flere sykdommer. Utvikling av ny teknologi gjør det nå mulig å detektere aktivering av antigenspesifikke T-celler ikke-invasivt og uten bruk av fargestoffer eller radioaktivitet (Nano Lett 2008; 8: 3310-4)

Den amerikanske forskergruppen benyttet ultrasensitive sensorer i nanostreng felteffekt-transistorer, og kunne slik måle strøm i nanostrengen avhengig av ladningen rundt sensoren. På denne måten kunne de spore $\mathrm{pH}$-forandringer i miljøet rundt aktiverte T-celler. T-celler aktivert av et uspesifikt anti-CD3-stimulus ble påvist i løpet av 10 sekunder, mens antigenspesifikk T-cellerespons viste seg 40 sekunder etter spesifikk stimulering med peptid/HLA-molekyl.

\section{Profylakse mot sepsis hos premature}

Profylaktisk behandling med cytokinet GMCSF hos premature barn reduserer ikke forekomst av sepsis eller mortalitet. Det er konklusjonen i en randomisert studie (Lancet 2009; 373: 226-33).

Studien omfattet 280 premature barn. De nyfødte var randomisert til å få GM-CSF daglig de fem første levedagene eller standard behandling.

Selv om mengden hvite blodceller økte raskere i GM-CSF-gruppen enn i kontrollgruppen, var det ingen signifikant forskjell i infeksjonsfri overlevelse mellom de to gruppene.

\title{
Kvinner med koronarsykdom har bedre prognose enn menn
}

\author{
Angiografisk påvist koronarsykdom \\ er mindre utbredt hos kvinner og \\ langtidsoverlevelsen er bedre enn hos \\ menn. Det viser en ny norsk studie.
}

Ved Feiringklinikken ble 18767 pasienter utredet for koronarsykdom i perioden mars 1999-2006. Overlevelse frem til mai 2007 ble fastslått ved opplysninger fra Folkeregisteret.

Målsettingen med studiet var å sammenlikne utbredelsen av koronarsykdom og den videre overlevelse etter første gangs invasiv undersøkelse hos kvinner og menn.

Studien omfattet 18767 pasienter, hvorav en tredel kvinner. Univariate analyser viste at kvinnene var litt eldre (64,8 år mot 62,3 år), hadde høyere ejeksjonsfraksjon, litt lavere endediastolisk trykk, mer subjektive symptomer, oftere hypertensjon, men sjeldnere iskemi på arbeidsbelastning. Det var også færre kvinner med tidligere infarkt, færre røykere og færre med tidligere revaskulariserende behandling. Den angiografiske undersøkelsen viste langt oftere ingen koronar- sykdom hos kvinner $(28,1 \%$ mot $10,5 \%)$, og sjeldnere trekarssykdom $(21,8 \%$ mot $38,7 \%$ ). Disse forskjellene var også signifikante i undergrupper uten tidligere revaskulariserende behandling og hos dem med stabile og ustabile symptomer.

Overlevelsesanalysene viste at ikke i noen undergrupper hadde kvinnene økt dødelighet, verken på kort eller på lang sikt. Cox-analysen viste en overdødelighet hos menn med hasardratio på 1,29 , men uten forskjeller mellom kjønnene i den undergruppen med høyest endediastolisk trykk.

Undersøkelsen tyder ikke på at kvinner kommer senere til invasiv utredning enn menn og viser at de faktisk har bedre prognose enn menn når man justerer for alder, komorbiditet og utbredelsen av koronarsykdom.

\section{Per Mølstad}

moelsta@online.no

Kardiologisk avdeling

Feiringklinikken

\section{Litteratur}

Mølstad P. Coronary heart disease in women: less extensive disease and improved long-term survival compared to men. Scand Cardiovasc J 2009; 43 $10-6$.

\section{Reaktive nitrogenforbindelser mot latent tuberkulose}

\section{Forbindelser som fører til intracellu- lær frigjøring av nitrogenoksid kan være effektive mot Mycobacterium tuberculosis.}

Reaktive nitrogenforbindelser spiller en viktig rolle i organismens forsvar mot mykobakterielle infeksjoner. Bisykliske nitroimidazoler kan omdannes til biologisk aktive metabolitter som kan generere reaktive nitrogenforbindelser, som nitrogenoksid. Nå har amerikanske forskere undersøkt effekten av slike metabolitter på Mycobacterium tuberculosis (1).

Den baktericide nitroimidazolen PA-824 omdannes til tre primærmetabolitter, hvorav hovedmetabolitten er den korresponderende des-nitroimidazol. Forskerne fant en positiv korrelasjon mellom danningen av denne des-nitroimidazolen og anaerob død av ikke-replikerende $\mathrm{M}$ tuberculosis. I tillegg beskyttet NO-fjernere (scavengers) mykobakteriene mot den letale effekten av PA-824-metabolitten.

- Tuberkelbasiller er obligate aerobe bakterier, og i tråd med dette har man tidligere ikke funnet effekt av metronidazol på aktivt formerende tuberkelbasiller, sier professor Harald G. Wiker ved Gades Institutt, Universitetet i Bergen. Derfor er det overraskende at beslektede komponenter har effekt. Det mest interessante ved PA-824 er at midlet skal kunne ha baktericid effekt både på latente tuberkelbasiller og på aktivt delende bakterier. Det er knapt utviklet nye midler mot tuberkulose siden rifampicin kom i 1970-årene, og nye midler er kjærkomne, særlig i lys av den omfattende problematikken rundt resistensutvikling.

- Virkningsmekanismene for PA-824 begynner å bli godt kartlagt, og mekanismer for resistensutvikling mot PA-824 er også delvis kjent. Hvis klinisk utprøving av midlet viser lovende resultater, vil PA824 ha potensial til å bli et viktig supplement i kombinasjon med noen av de øvrige anti-tuberkuløse midlene, sier Wiker.

\section{Trine B. Haugen \\ trine.b.haugen@hf.hio.no \\ Tidsskriftet}

Litteratur

. Singh R, Manjunatha $\mathrm{U}$, Boshoff $\mathrm{HI}$ et al. PA-824 kills nonreplicating Mycobacterium tuberculosis by intracellular NO release. Science 2008; 322: 392-5. 